\title{
Proteasome Assembly Chaperone 2
}

National Cancer Institute

\section{Source}

National Cancer Institute. Proteasome Assembly Chaperone 2. NCI Thesaurus. Code C104901.

Proteasome assembly chaperone $2(264 \mathrm{aa}, \sim 29 \mathrm{kDa}$ ) is encoded by the human PSMG2 gene. This protein plays a role in promoting assembly of the $20 \mathrm{~S}$ proteasome. 